\title{
Problems with the Essentialist Definitions and the Institutional Theory of Art
}

\author{
LOK CHONG HOE \\ School of Humanities, Universiti Sains Malaysia \\ 11800 USM Pulau Pinang, Malaysia \\ chlok@usm.my
}

Published online: 15 October 2016

To cite this article: Lok, C. H. 2016. Problems with the essentialist definitions and the institutional theory of art. KEMANUSIAAN the Asian Journal of Humanities 23(2): 9-33, http://dx.doi.org/ 10.21315/kajh2016.23.2.2

To link to this article: http://dx.doi.org/10.21315/kajh2016.23.2.2

\begin{abstract}
This paper investigates the major weaknesses in essentialist art theories including a transformed new version known as the institutional theory. Proponents of the institutional theory like Danto and Dickie believe that the essence of art is a relational (rather than physical) property, with Dickie arguing that the two common characteristics are: (i) the work must be an artefact; and (ii) there must be someone or institution that confers on it the status of object for appreciation. I will show that such institutional theories may describe a necessary property, but never the sufficient property of art. This means that like traditional essentialist theories, they (also) fail to identify the essence of art. I will then argue in support of Morris Weitz's claim that art is an open concept, and its capacity for incorporating very novel and different objects or activities makes it impossible (and a waste of effort) to describe the necessary and sufficient conditions of art.
\end{abstract}

Keywords and phrases: essence, necessary and sufficient properties, essentialist definition, institutional theory of art, open concept

\section{Traditional Essentialist Theories of Art}

Aesthetic theories have in the past attempted to define art by a description of its necessary and sufficient properties. It was hoped that these essential properties will then enable us to differentiate art from other things or activities. Traditionally, essentialist theorists have adopted three possible strategies. Firstly, a theory could describe a particular feature or characteristic found in works of art, and then consider it as both the necessary and sufficient property of art (Collingwood's theory of expression, and Bell's theory of Significant Form, are good examples of this kind of theory). Secondly, a theory could list a set of

(C) Penerbit Universiti Sains Malaysia, 2016 
characteristics - claiming each characteristic as necessary, and the entire set as sufficient, for something to be a work of art (Aristotle's definition of tragedy, which can be extended into a full-blown theory of art, is the best example here). And thirdly, a theory could list a set of characteristics so that possessing any one of these characteristics is sufficient for something to be regarded as art (Plato's theory, which I will describe below, is an example of this). I shall call these the traditional essentialist theories of art, to differentiate them from the institutional theory of art which does not focus on features or characteristics that are visible on works of art.

Now both Plato and Aristotle consider art as one form of mimesis (imitation)and by describing the kind of mimesis that art is engaged in, we also describe the necessary and sufficient properties of art. In the case of Plato mimesis includes: (i) reproducing the speeches, tones and gestures of another person; (ii) making an accurate copy or likeness of the real thing; (iii) impersonating somebody; and (iv) representing men in action (see Plato, Republic X, 597e, 598 b-c, Republic II, $377 \mathrm{e}$, and Republic III, 393a-b; see also Lok 2007, 120-122 ). This is supposed to be a list of the sufficient conditions of art, for any art form (or artwork) must fit at least one of these four kinds of mimesis. Aristotle (who started as one of Plato's students) did not draw out an essentialist definition of art, but he did so for one form of art (i.e., tragedy) which some Aristotelians argue could be stretched or extended into a full-blown definition of art. Aristotle defines tragedy (one form of art) by the six elements of plot, character, thought, diction, melody and spectacle. But Eva Schaper (see Schaper 1968, 79-115; and Lok 2010, 124-145) has derived six essential features in art from Aristotle's six elements of tragedyplot was extended to theme (like plot in tragedy, theme allows us to see the various parts of an artwork as "hanging together" or forming a coherent whole), character to internal integrity (in tragedy character or settled disposition coordinates the actions of the dramatis personae, while in the other art forms components or parts are coordinated through internal integrity to form an intelligible whole), thought to artistic symbolism (in tragedy words and verbal expressions point beyond themselves to thoughts, while in the other arts certain features may evoke feelings and mental states - a process we consider as symbolism in the arts), diction to the means of articulation (in tragedy diction is employed as the means for making the plot evident to the audience, while in the other arts paint, marble, bronze, wood, sounds, etc., may be the means for articulating the work and making it evident to the spectators), melody to devices meant for separating the artwork from its surrounding environment (because melodic expression is strange and very different from daily discourse, it separates the tragic drama from its surroundings so that it is not seen as an extension of daily life - the other arts employ different devices to achieve the same aim, such as pedestals in sculptures, frames in paintings, musical timing in music, etc.), and spectacle is extended to the requirement of presentational immediacy (which 
spectacle stresses the requirement for the tragic play to be presented to the audience, other arts must also satisfy this requirement of being able to be presented to the senses of its audience). By extending Aristotle's theory on tragedy to a theory on art, Aristotelians like Schaper are able to claim that Aristotle actually has a full-blown theory of art which describes the necessary and sufficient properties (of art).

But essentialism is not confined to those who consider art as a form of mimesis. Expression theorists can also be considered as proponents of essentialism in art. R. G. Collingwood believes that the artist will discover what his emotion is in the process of creating his artwork. In other words, the creation of the artist's work and clarification (or self-discovery) of his emotions are one and the same process (see Collingwood 1958, 122-123). This is certainly an essentialist definition-for (according to Collingwood) any artwork must necessarily satisfy this condition, and anything that fulfills this condition is art. In fact works of craft cannot satisfy this condition, because the craftsman will try to employ the best means to attain an end which is already known to him - a carpenter knows how his chair would look like before applying the best means for producing it. There is therefore no expression, because expression entails that the artist does not know the end, and only the process of creating the artwork could bring the end to light (i.e., he then knows the nature of his emotion, or what his emotion actually is). And expression (the process of expressing oneself) is the necessary and sufficient condition of art. However, the clearest case of an essentialist definition is provided by Clive Bell (Bell 1958, 17-18) on art as Significant Form:

For either all works of visual art have some common quality, or when we speak of "works of art" we gibber. Everyone speaks of "art," making a mental classification by which he distinguishes the class "works of art" from all other classes. What is the justification of this classification? What is the quality common and peculiar to all members of this class? Whatever it be, no doubt it is often found in company with other qualities; but they are adventitious - it is essential. There must be some one quality without which a work of art cannot exist; possessing which, in the least degree, no work is altogether worthless. What is this quality? What quality is shared by all objects that provoke our aesthetic emotion? What quality is common to Sta. Sophia and the windows at Chartres, Mexican sculpture, a Persian bowl, Chinese carpets, Giotto's frescoes at Padua, and the masterpieces of Poussin, Piero della Francesca, and Cezanne? Only one answer seems possible - significant form. In each, lines and colors combined in a particular way, certain forms and relation of forms, stir our aesthetic emotion. These relations and 
combinations of lines and colors, these aesthetically moving forms, I call "Significant Form"; and "Significant Form" is the quality common to all works of visual art.

Bell has introduced his essentialist definition of art in a more lucid way than anyone else. "Significant Form" (or the combination and relation of certain lines, forms and colours) is the necessary and sufficient feature in every work of art-it will be found in combination with other features, but they are only accidental features which are not essential to artworks; while Significant Form is definitely essential and to be found in each and every work of art. And anything that has Significant Form must be a work of art (in other words it is also the sufficient condition of art-hood). Examples of such essentialist definitions (or theories) of art can be multiplied - but I have already mentioned a sufficient number of these theories, and describe more examples would be quite redundant.

\section{Problems with Essentialist Theories of Art and "Family Resemblances"}

The core problem in essentialist theories of art is they are either too narrow or too broad, or both. Clive Bell's Significant Form probably cannot be extended to include some of the most important art pieces and art activities of the 20th and 21 st centuries. It would be nonsensical to talk about Significant Form (that special combination and relationship of lines, shapes and colours) in Marcel Duchamp's Fountain (1917) which was actually a urinal taken from a public toilet and signed R. Mutt. And if Bell insists that the Fountain or urinal has Significant Form, then he must say that all urinals that share that shape and form and colour (including those that were still used in American public toilets in 1917) are actually works of art. So either Bell's definition is too narrow (and cannot include Duchamp's masterpiece), or it is so broad that it must include all urinals of the same shape and colour in the public toilets. The other alternative would be for Bell to dismiss the Fountain as a work of art-but this may not work because most of the artworld (consisting of art museums, art critics, art theorists, art historians, published books on art, and art lovers in general) have accepted it as an important work of art that broke new ground and allowed for the entry of ready-mades (or manufactured and found objects) into the category of art. And so Bell's theory is either too narrow (it cannot, for instance, include Duchamp's ready-mades such as Fountain), or too broad (it may include Duchamp's Fountain, but at the expense of including all urinals of the same shape and colour), or both. One could argue that most essentialist theories of art suffer a similar problem. 
Perhaps the most notorious anti-essentialist aesthetician was Morris Weitz. Weitz considers the concept "art" to be similar to the word "games" in at least one respect. Ludwig Wittgenstein (Wittgenstein 1958, 65-67) claims that there is no single or set of characteristics common to all the activities and things we call "games." Instead there are "family resemblances," or an overlapping set of characteristics where none of them is common (or necessary) to all the things we consider as "games." In family resemblances we do not see one common characteristic in all the members of the family-some members will have the same nose, some similar eyes, some similar hair and lips, some similar cheek bones, etc., without any of these characteristics being common to all the members. The same is true of games. Now Weitz extends this to the concept "art," which likewise has family resemblances but not necessary and sufficient properties. But Weitz $(1956,29)$ goes further to argue that this was because "art" is an open concept:

New conditions (cases) have constantly arisen and will
undoubtedly constantly arise; new art forms, new movements
will emerge, which demand decisions on the part of the
interested, usually professional critics, as to whether the concept
should be extended or not. Aestheticians may lay down
similarity conditions but never necessary and sufficient ones for
the correct application of the concept. With art its conditions of
application can never be exhaustively enumerated since new
cases can always be envisaged or created by artists, or even
nature, which would call for a decision on someone's part to
extend or to close the old or to invent a new concept... What I
am arguing, then, is that the very expansive, adventurous
character of art, its ever present changes and novel creations,
makes it logically impossible to ensure any set of defining
properties.

Art as an open concept means that there will not only be constant innovations, but innovations that continuously disrupt prior categories. One way this could happen is when emerging new cases do not possess prominent or important features that are found in the earlier (accepted) cases of art. One may consider Marcel Duchamp's Fountain (1917) as a good example, for this urinal which was detached from a public toilet and signed R Mutt by Duchamp does not possess any of the significant features that are found in traditional paintings and carved or molded sculptures. "Art" is an open concept because such new cases will force us to decide whether or not they should be considered as works of art-and the decision will be based not on necessary and sufficient conditions (because such conditions do not exist) but whether they have sufficient similarities (family resemblances) to be accepted as art. 
But Weitz's position seems a little weak. If there is continuous innovation where new cases seem not to possess important features in traditional or accepted works of art, this does not imply that a common feature may not actually exist in art. There may still be a hidden common feature which none of artworks or different art movements chose to emphasise. In other words, Weitz has not explained why continuous innovations which emphasise new features must necessarily imply an absence of necessary and sufficient properties (after all the common and necessary property may never have been emphasised as an important feature of art by any accepted or new cases).

Maurice Mandelbaum (1965, 219ff) was probably aware of this weakness when he argues that the phrase "family resemblances" implies that there is at least one common property among the members that possess them-and this common characteristic is biological ties or relation. We may see similarities between many people (e.g., Adolf Hitler and Charlie Chaplin) but we do not consider these similarities as "family resemblances" simply because biological relationship (the common property) is missing. This, argues Mandelbaum, was probably what Wittgenstein had in mind when he employed the word "family resemblances" to refer to similarities between games (instead of simply "similarities"). The same can be said for the arts - if artworks have "family resemblances" (instead of mere similarities) then there must be some common characteristic between them. $\mathrm{He}$ then argues that this common property may not be something that is visible or physical - it is probably something that is relational (like biological relationship between people who possess "family resemblances"). The mistake of many earlier aestheticians was to describe visible or physical properties as the common characteristic in art.

Mandelbaum has clearly misrepresented Wittgenstein by saying there must be a common property in games since they (games) have "family resemblances." I believe it is quite clear that Wittgenstein used "family resemblances" with an extended sense, and not with its usual meaning. It is true that "family resemblances" in its usual sense implies the presence of a common characteristic in the members who share them, i.e., biological relationship. But a common property has been ruled out when Wittgenstein $(1958,31-32)$ wrote:

Consider for example the proceedings that we call "games." I mean board games, card games, ball games, Olympic games, and so on. What is common to them all?-Don't say: "There must be something common, or they would not be called 'games'"—but look and see whether there is anything common to all. For if you look at them you will not see something that is common to all, but similarities, relationships, and a whole series of them to 
that... And the result of this examination [i.e. observation] is: we see a complicated network of similarities overlapping and crisscrossing: sometimes overall similarities, sometimes similarities of detail. I can think of no better expression to characterize these similarities than "family resemblances"; for the various resemblances between members of a family: build, features, colour of eyes, gait, temperament, etc., etc., overlap and crisscross in the same way-And I shall say "games" form a family.

I admit to a certain degree that Wittgenstein may have chosen a better expression than "family resemblances" to describe these similarities in the activities we call games, simply because this phrase can be exploited by people like Mandelbaum to stress there is a common relational property (between members with family resemblances), i.e., biological ties. But it is clear that from the above quotation that when using the phrase "family resemblances," Wittgenstein wanted to stress there is no common feature (or characteristic) in the activities we call "games" (and this is exactly the opposite of what Mandelbaum suggests he was trying to do). Wittgenstein was struggling to find the proper expression to describe this network of similarities, and he settled for some kind of extended notion of "family resemblances," where not a single one of these resemblances is common to all the members of the group (i.e., the group of activities we call "games").

Despite misrepresenting Wittgenstein, Mandelbaum's claim that the common property in art must be a relational property and not something that is physical or directly observable (property) has quite an influence on the development of modern aesthetics. For example, some aestheticians in the 1960s developed the institutional theory of art-something is a work of art not because it has some directly observable property like Significant Form, but because it has some important relationship with society, or institutions in the society, which legitimises it as "art." I will therefore focus now on the institutional theory, and see whether it successfully identifies the essential property of art.

\section{Two Prominent Institutional Theories of Art}

One theory that challenges the anti-essentialist position (of Weitz) is the institutional theory of art, introduced by Arthur Danto and George Dickie. They believe that essentialist theories have in the past made the mistake of focusing on directly observable characteristics - however, the common characteristic in all artworks is not something that can be extracted by looking at works of art. If there is a common characteristic, this can only be found in some kind of relationship that art has with certain institutions in society (or some kind of action by someone, which then allows us to see something as a work of art). 
Danto and Dickie therefore focused on this property which is not directly observable, rather than some characteristic which can be seen on (all) artworks.

Danto argues that we can distinguish art from non-art because there is "an atmosphere of artistic theory, a knowledge of the history of art" (Danto 2007, 214). In order to understand what Danto means, consider his discussion on Brillo cartons displayed by Pop artist Andy Warhol (see Danto 2007, 214-215). Now why are Brillo cartons displayed by Warhol considered as art, while similar cartons in a nearby supermarket are not? In order to see the distinction one requires knowledge of both theory and history of art. According to Danto (2007, 215):

What in the end makes a difference between a Brillo box and a work of art consisting of a Brillo Box is a certain theory of art. It is the theory that takes it up into the world of art, and keeps it from collapsing into the real object which it is (in a sense of is other than that of artistic identification). Of course, without the theory, one is unlikely to see it as art, and in order to see it as part of the artworld, one must have mastered a good deal of artistic theory as well as a considerable amount of the history of recent New York painting.

Notice that for Danto, the artworld consists principally of our knowledge of art theory (or theories) and art history. If one is to be able to see something as art, one must have adequate knowledge of art theory (theories) and art history. In order to see Marcel Duchamp's urinal (a ready-made object entitled Fountain, 1917) as art, we must know something about the relevant art theory (an ordinary object, including one normally placed in a toilet, may be viewed aesthetically, in the same way that usual art objects like paintings and sculptures are viewed aesthetically), as well as art history (in western art, there is the tradition of challenging established aesthetic values and beliefs, which Duchamp is doing by exhibiting ready-mades in an art museum). If the knowledge of the relevant theory and history were taken away, Duchamp's urinal would just be an ordinary urinal which rightfully belongs in a men's toilet. As editor Wartenberg (2007, 206) elegantly wrote while explaining Danto's notion of "artworld," "to be an artwork requires that the object occupy a place in the history of art, something that it does in virtue of the presence of a theory (or interpretation). Without a prior understanding of art history and theory - in short, of the artworld-a viewer could not see an object as a work of art." Any art object (or art activity) has a proper location within the history of art-as new art theories are developed and introduced and accepted in this environment of art history. Duchamp's urinal will probably be rejected as art in the Renaissance Period (for no theory existing at 
that time could ever accommodate it as art); it can only be accepted as art from the early 20th century onwards - for it was only then that new theories have been developed that enable us to perceive art in new ways, and extend the concept (of art) to include radically new things like ready-mades. Theory and history are therefore the necessary conditions for anything to be accepted as art.

Dickie seems to use the concept "artworld" with a broader meaning. He considers the artworld as an institution, which means that it has certain established practices-established practices governing the display and presentation of artworks, reactions of the audience, and acceptance of something as a work of art. According to Dickie $(2007,221)$ :

This institutional behavior [in theater] occurs on both sides of the "floodlights": both the players and the audience are involved and go to make up the institution of the theater. The roles of the actors and the audience are defined by the traditions of the theater. What the author, management, and players present is art, and it is art because it is presented within the theatre-world framework. Plays are written to have a place in the theater system and they exist as plays, that is, as art, within that system.

Dickie's notion of artworld consists not only of art theories and art history (as in Danto's case), but also conventions (or established practices) governing the presentation of artworks, the management of artworks (e.g., they are often kept in art museums), our reactions to artworks (e.g., what the audience of a theatre could or could not do while a play is being staged), etc. But this artworld is only a part of his much broader definition of art. In Dickie's $(2007,223)$ definition, a work of art "in the classificatory sense is (1) an artefact; (2) a set of the aspects of which has had conferred upon it the status of candidate for appreciation by some person or persons acting on behalf of a certain social institution (the artworld)". "Artefact" suggests that artworks are man-made and not naturally present, but it must be capable of incorporating a natural landscape or rock which someone (e.g., the artist) has proclaimed as a work of art-in this way it is better to describe "artefact" as something which is the product of human conception, so that the description can include something that occurs naturally but given the status of an artwork by the artist or critic. In doing so we get into Dickie's second condition-i.e., certain individuals representing or acting on behalf of the artworld have the capacity to confer the status of art on new or novel cases that are being introduced from time to time. Dickie $(2007,224)$ argues that this conferring of status for appreciation (or art) is usually carried out by the artist: 
In one sense a number of persons are required but in another sense only one person is required: a number of persons are required to make up the social institution of the artworld, but only one person is required to act on behalf of the artworld and confer the status of candidate for appreciation. In fact, many works of art are seen only by one person - the one who creates them-but they are still art. The status in question may be acquired by a single person's acting on behalf of the artworld and treating an artifact as a candidate for appreciation. Of course, nothing prevents a group of persons from conferring the status, but it is usually conferred by a single person, the artist who creates the artifact (italics are from the original text).

Dickie then goes on to argue that there is a difference between simply presenting an object for appreciation and actually conferring on it the status of object for appreciation (which, in this context, makes it an artwork). A plumber may display a urinal which he has repaired for our appreciation, but unlike Duchamp's Fountain (1917), it will not be classified as art (Duchamp presented his urinal as a candidate for appreciation in 1917, and it has subsequently been accepted as art). The reason, according to Dickie $(2007,225)$, is that "Duchamp's action took place within the institutional setting of the artworld and the plumbing salesman's action took place outside of it." The artworld (in Dickie's scheme) consists principally of "established practice," or a set of conventions and rituals pertaining to works of art-how an artwork is presented (e.g., it should be presented in an art museum or gallery or some space which has been declared as appropriate for presenting an art activity), the accepted or "institutionalised" behaviour of the spectators and actors, the roles of the management, actors, artists, and spectators, etc. In other words, Duchamp's urinal (Fountain) was presented within this set of conventions, while the plumber's urinal was outside of it - which was why the former is art while the latter is not. But surely Dickie's artworld must also incorporate art history and theory (which were emphasised by Danto), for art conventions and rituals are certainly determined by history and theory. In fact one cannot overstate the role played by art theory in the inclusion of Duchamp's Fountain as art, and the rejection of the plumber's urinal into the category. It was the emergence of new theory (and new thinking about art) that enabled us to accept as art things that are readily available (or ready-mades) and not created by the physical skill of the artist. 


\section{Agents or Institutions which Confer the Status "Works of Art" on New Cases}

Dickie $(2007,223)$, however, argues that although the artworld is made up of people with different functions and skills ("painters, composers, writers, producers, museum directors, museum-goers, theatre-goers, reporters for newspapers, critics for publications of all sorts, art historians, art theorists, philosophers of art, and others"), it is usually the artist, or creator of the artefact (and not the others who made up the artworld), who confers the status of "object for appreciation" on his work. He (Dickie 2007, 224) insists that although "nothing prevents a group of persons from conferring the status [of object for appreciation on an artifact]... it is usually conferred by a single person, the artist who creates the artifact." There are at least two possible objections here. First, in conferring the status of "object for appreciation," the roles played by some (if not all) of the other elements of the artworld are as important as that played by the artist. One must not ignore the important role played by the art critics, theorists, aestheticians, and art historians (as emphasised by Danto). It is true that Marcel Duchamp was responsible for placing a urinal in an art exhibition in 1917, and naming it Fountain, as well as signing on it. We can also say that Duchamp has proposed his ready-made as a work of art, or as an "object for appreciation." However, it is not yet being conferred the status of art until all or most of the other elements of the artworld (especially the art theorists, critics, and art historians) accept it as art. Now, if all or the vast majority of art critics, art historians, theoreticians and spectators had rejected Duchamp's work as art-and continue to reject it - the Fountain (1917) may not have ended up as a work of art today. It must be noted that not every attempt by an artist to confer the status of "object for appreciation" on his work is successful. A relatively unknown artist who tries to introduce something completely radical and new will probably not succeed. In 1974 a young artist named Redza Piyadasa returned from Hawaii and attempted to introduce conceptualism to Malaysia. His exhibition entitled Towards a Mystical Reality did not receive any attention from either the local or foreign press. The works in this exhibition were finally mentioned in a locallypublished book on modern Malaysian artists, a book that was jointly written by the artist (Piyadasa) and his good friend Kanaga Sabapathy. After that, no one bothered to mention the exhibition or the works that were exhibited (newer books on modern Malaysian art completely ignored them), and the Malaysian artworld appears to have almost forgotten them. So the artist alone cannot sufficiently confer the status of object for appreciation on his work, and neither would the support of one or a few relatively unknown writers be sufficient. Duchamp's Fountain (urinal) was able to enter the realm of art because of sustained support in the writings of well-known art critics and historians through many decades-a feat which Piyadasa's works were not able to achieve. Second, some works may have been conferred the status of art even though their creators never intended 
them to be so-e.g., stoneware bowls, bronze lamps, porcelain flower pots, etc., which were in the past used as household utensils but have been elevated to "objects for appreciation" in art museums, etc. Such elevation of the status of ordinary household items from the past can only be achieved by a shift in aesthetic beliefs and tastes, and the publications of art critics and aestheticians may play a great role in changing beliefs to allow the conferring of the status of art on these objects. It is therefore not always necessary for the maker of the object to confer the status of "object for appreciation" on his artefact-sometimes the artefact could be elevated to this status without the effort or consent of its maker. We cannot say that the effort of the maker (artist) is more always important than the views of art critics and changes in art theory.

One must not forget that books or papers (in journals) that introduce or discuss new artworks or activities can be construed as attempts to legitimise these new "works" as art. While discussing radical art a little later in this paper, I will be referring to written sources, and especially Gavin Grindon's (ed.) Aesthetics and Radical Politics. I will argue that this book can be seen as an attempt to confer the status of art (or art activity) on all those political and semi-political activities which it describes. After all, the artworld also contains art critics and aestheticians, and their published writings can play a vital role in conferring the status of art on certain radical political activities.

\section{Problems in Danto's Version of the Institutional Theory}

I have so far directed my criticisms largely at Dickie's version of the institutional theory, but Danto's version has a similar weakness. Instead of stressing the role of institutions conferring the status of art, Danto emphasises knowledge of theory and history - in order to recognise and understand an object (or activity) as art, one needs knowledge of both art theory and history (only by knowing the relevant art theory may we know what place or position it occupies in the history of art). But this may not sufficiently explain why certain works that satisfy the twin criteria of theory and art history may yet fail to gain acceptance as art. Take again Piyadasa's experiment with conceptualism in Malaysia in the 1970s. Like Warhol's brillo box (Danto's example to show that one needs knowledge of the relevant theory to see something as art), one needs at least some knowledge of the writings of the conceptualists to recognise Piyadasa's wooden chair, human hair and hung iron bird cage as "art." Furthermore, Piyadasa's works can be said to occupy some sort of position in Malaysian art history-artists and scholars have been sent to Europe and America from the early 1960s and returned with challenging new ideas that altered and transformed traditional Malaysian art in various directions, and Piyadasa's introduction of conceptual works may be seen as one of these influences that transform the rich landscape of Malaysian art in 
the 1970s. However, while many of these foreign influences have today been accepted and incorporated into the rich tapestry of Malaysian art, Piyadasa's conceptual works appear to have been deliberately left out. Maybe it was local religious sentiment that excluded Piyadasa's works (if he exhibits real chairs and human hair, may he not also exhibit real cats and humans which are the creations of God?). Whatever the reason, there are surely many artists around the world whose works fully satisfy the twin criteria of theory and art history but (for some reason) fail to get recognised as art. Danto's theory (like Dickie's) may have failed to describe the sufficient conditions of art (if those conditions really exist).

But I wish to return to Dickie's theory so that I may focus on his claim of institution conferring the status of art (on certain artefacts). Firstly, I am not pretending there are no other criticisms thus far of the institutional theory-but my criticism may be the only one that directly shows its inability to describe the sufficient conditions of art (if such conditions really exist) - hence its inability to function as a proper essentialist theory. But there are other criticisms that are equally (or even more) destructive. For example, Alexander Erler points out that Dickie's theory amounts to nothing more than a sociological report, and is therefore not a true art theory - this is because it only describes what society "dominantly considers to be art, rather than a statement of what art actually is, no matter what the prevailing view may be about it in the artworld" (see Erler 2006, 114). A proper art theory is normative in nature, and will offer good grounds for what art ought to be-now even if a particular theory acknowledges that the concept of art evolves from decisions made by powerful representatives of the artworld, such decisions must be supported by reasons that can conform with our intuitions of what is or is not art-and the theory must reveal or discuss these reasons (see Erler 2006, 114-115). To ignore the normative aspect makes Dickie's theory completely inadequate as an art theory.

Erler may have a powerful criticism of Dickie's theory, but I wish to return to a different weakness in the theory. I will employ examples to demonstrate that Dickie's theory does not sufficiently describe the conditions for distinguishing art from non-art. To do this I will first discuss certain recent trends, especially activities which are called "radical politics." I will then argue that even though these activities could fulfil Dickie's two conditions, there is still a chance (or possibility) that they may not, in the long run, be accepted as art by society at large.

\section{An Attempt to Confer the Status of "Art" on Radical Politics}

Now, since the beginning of the 20th century we have encountered new or emerging art movements in the West that challenge aesthetic beliefs held by the 
majority of people in society - a good example is the Dadaist revolution (and particularly Marcel Duchamp's ready-mades). Their challenges have often expanded the category of art to include a variety of new things and activitiesperhaps most people within the art circle now expect this expansion of the concept of art to carry on indefinitely in the future - and this seems to support Weitz's claim that "art" is an open concept. However, this situation does not imply that everything (or every activity) introduced by emerging art movements will necessarily be accepted into the category of "art." In fact there are many instances of the so-called "new art" (or new art activities) that have not yet been fully legitimised by society at large, or even the artworld (I will henceforth use the term "artworld" in the same manner as George Dickie). And it is here that Dickie's institutional theory reveals a glaring weakness-i.e., it is not able to explain why some attempts to confer the status of "object for appreciation" fail. In other words there can be new cases (introduced by the more creative artists) that satisfy all the conditions of art stated by Dickie, and yet fail be regarded as art-which means that Dickie's theory has failed as an essentialist definition for not adequately describing all the sufficient conditions of art. I will support this point by referring to what has been labelled as "radical politics" or "radical art" by some writers.

I will discuss radical art by referring to a book on aesthetics (although it is more accurately considered as a collection of papers presented in a conference). Now, in Aesthetics and Radical Politics (Grindon 2008), scholars discussed what I believe are two different groups of activities-and both groups are lumped together as "radical politics," which are considered here as aesthetic activities. The two groups are: (i) activities or works that have already been accepted by society or the artworld as art; and (ii) activities that are probably not accepted (or at least not yet accepted) as art activity by society or even the artworld. Examples of the former group include discussions on Trocchi's Invisible Insurrection of a Million Minds (Gardiner 2008, 70-71) and Joseph Beuy's actions, including one entitled How to Explain Pictures to a Dead Hare which was conducted in a New York gallery (Ekstrand and Wallmon 2008, 46); and examples of the latter group include the Berlin and Hamburg Umsonst activities (discussed by Kanngeiser 2008, 1-23), the soma exercises (conducted in the conference) which are classified as an anarchist experiment (Goia 2008, 56-62), and attempts at explaining anarchism (Gordon 2008, 104-125), etc. It is the second group that is problematic — and which we will focus on. But let me first say a few things about the first group. Alexander Trocchi's Invisible Insurrection of a Million Minds is a collection of literary pieces compiled by A. M. Scott in 1991 (after Trocchi's death in 1984). As a collection of fictional or literary pieces, Trocchi's work will have no problem being accepted by the artworld as a literary work of art (no matter how rebellious Trocchi might be to established societal values; and no matter how lowly a skeptic might rate the quality of his literary pieces). 
Joseph Beuy's actions may challenge traditionally and commonly held notions on art (e.g., he proclaims that everyone is an artist, and art activities can function to dismantle our senile social welfare system - see Ekstrand and Wallmon 2008, 50 ), but they were about art and the role of art, and held in art galleries which were (and still are) regarded as proper platforms for displaying or channelling art to the public, etc. Most members of the artworld will not have problems accepting his actions as art-activity, given that they were performed in the proper context (the art gallery) and were concerned with issues relating to art (or what art should be). However, the second group (of activities) does not have these characteristics that can make them recognisable as art (or art activity). The artworld would probably be very reluctant to accept the activities of the Berlin and Hamburg Umsonst as art because: (i) the objective of these activities was social and economic in nature, i.e., to ensure that luxuries like swimming pools, art galleries, and exclusive supermarkets "should not be denied to those who cannot afford them and have an interest in them," and the struggle to make them available for all "should be placed alongside the struggle for basic material necessities such as food and housing" (Grindon 2008, xiii); (ii) the participants do not think (nor were aware that) they were engaged in any activities related to art - they participated principally to achieve their goal of bringing greater fairness to society; and (iii) the environment in which they participated - they occupied swimming pools, exclusive supermarkets, etc.-were not then considered as part of the art context, in the same way exhibits displayed in an art museum or gallery can be said to have taken place within an art context (I will clarify the meaning of "art context" a little later). These points can also be made on the soma anarchist experiments conducted in the conference (Goia 2008, 5662 ), as well as many of the other "works" described in this book.

At this stage one could ask why Aesthetics and Radical Politics has included discussions on this second group of works. There are two possibilities: (i) this book classifies all the works discussed in it as art (including those political activities which have not yet been accepted as art by the majority in the art circle); and (ii) this work only wants to show that all these activities it discusses can be viewed or appreciated from aesthetic perspective. Now, in order to get a clearer picture of its objective, I refer to an assertion made by the editor, Gavin Grindon, in his introduction (Grindon 2008, vii):

Within the realm of aesthetics, the situation is particularly thatas the case studies presented by the articles in this volume demonstrate - this movement [of critical young scholars] often seeks to aestheticise politics, or rather, to treat the aesthetic as a directly political terrain... 
From Grindon's claim (above) as well as papers in the book, it is still not clear how these young scholars seek to "aestheticise politics." The confusion here lies in the difference between considering an activity as "art" or simply viewing it from the aesthetic perspective. Any object or activity can be approached from the aesthetic perspective, but this does not make it an art object or art activity. We can admire the aesthetic beauty of the Space Shuttle, or a football match, without at the same time treating these things as works of art in the strict sense. On the other hand, a clear-cut case of art (e.g., Michelangelo's David, or an activity performed by a conceptual artist) will demand that we adopt an aesthetic approach when criticising or commenting on it - which we need not do in relation to the Space Shuttle or football match. As to those who "seek to aestheticise politics" (see quotation above) it is often unclear whether they choose only to approach such activities from the aesthetic perspective (in the same way that we can approach a gymnastics display from the aesthetic angle), or consider them as clear-cut cases of art (or art-activity).

If we treat all the activities described in Aesthetics and Radical Politics as art (or art activity), then we will face the problem that some of those activities (e.g., the Hamburg Umsonst activism described by Kanngeiser, or the Soma experiments described by Goia, or the discussion on anarchism in Gordon's work, etc.) are either not art per se, or have yet to be accepted by the artworld as "art." On the other hand, if we regard this book as simply employing the aesthetic approach to viewing and discussing certain socio-political activities, then it must explain why it employs this approach to both activities that are clearly not art as well as those which are clear-cut cases of art or art activity (e.g., novelist Alexander Trocchi's "Invisible Insurrection of a Million Minds" (1991, 70-71), or even Joseph Beuy's action How to Explain Pictures to a Dead Hare which at least was conducted in an art context, i.e., a gallery in New York, see p. 46) - or at least the artworld would have no difficulty accepting these as art. If the aim is to show that the aesthetic approach can be employed for viewing radical socio-political activities, then incorporating clear cases of art activity will serve no purpose, as they are meant to be appreciated from the aesthetic angle anyway.

However, I believe this book cannot be (simply) an attempt to view certain radical political activities from the aesthetic perspective. The fact that both clear cases of art (e.g., Trocchi's works) as well as questionable cases (e.g., the Hamburg Umsonst activism) are packaged in the same book already suggests that they are (both) meant to be seen as belonging to the same category - the category of "art." In other words, it may be argued that this book (Aesthetics and Radical Politics) wants be seen as one of the agents which, acting on behalf of the artworld, attempts to confer on those political activities (mentioned in the book) the status of candidates for artistic appreciation. In short, this book is an accepted agent (representing the artworld) for legitimising these activities as art (or art 
activities). We will discuss whether this and other such attempts to confer the art status on radical political activities can be successful.

\section{Attempts to Confer the Status of Art on Certain Radical Political Activities May Not Necessarily be Successful}

I have pointed out that Aesthetics and Radical Politics must be seen as an attempt to confer the status of art (or "activities for appreciation") on those activities described in the book. Or it must at least be construed as a proposal to view those activities as art-activities.

But I have also asserted that this book (or the papers in it) describes both clearcut cases of art as well as those which probably have not yet been accepted by the artworld. The question is: will this inclusion of clear cases of art (in the book) necessarily influence the reader into accepting the more contentious cases as art? Not necessarily, if the reader is a critical reader. Firstly, those who initiated the Berlin and Hamburg Umsonst protest activities do not see themselves as artists, nor do they see their campaigns as art (or art-activities). Kanngeiser has elegantly phrased their intention(s) in the following question: "why should we be denied 'luxuries' just because we don't have the financial resources required to take part?" (6). The slogans of the Umsonst activists also make their intention clear"everything for everyone," and for free too (see pages 10 and 12). The intention of the participants is political, social, and economic in nature: to enable poorer segments of society an equal opportunity to enjoy expensive and exclusive facilities - swimming pools, exclusive supermarkets, and other such luxuries (see the introduction, xiii). Like the anti-capitalist "Occupy Wall Street" international movement in 2011, the Hamburg Umsonst activists never had intentions or goals that were aesthetic in nature. As stated earlier, this is unlike Joseph Beuys' social sculptures, which were presented in art galleries as art performances (i.e., the artist intended for his works to be seen as art), and the audience who visited the gallery to see Beuys' exhibition will expect to see some form of art or art performance. The same can be said for Marcel Duchamp - his ready-mades were intended to be seen as art (i.e., they were introduced in an art context). Furthermore the ready-mades were meant to challenge traditional views on art (which was why they were exhibited in art galleries) - and this implies that they were meant to play some sort of aesthetic function. Hence, the Hamburg and Berlin Umsonst protest activities are contentious because: (1) they are not intended by the organisers as art-activities; (2) their organisers and participants do not see themselves as artists; (3) the protest activities do not appear to have any aesthetic function; and (4) the audience, or those who witness the protests, do not expect to see an art performance (they probably saw them as political or social protests). These points can also apply to the soma anarchist therapy 
performed at the venue of the conference. The declared aim of soma anarchist therapy is to help participants develop skills for horizontal relationships, in order to resist vertical relationships based on domination by others in everyday life (58 and 61). Despite Goia's insistence that soma is a form of "life art," its aim is essentially social and political in nature; and the fact that it was carried out in the conference does not imply it operated within the art context (the conference is an arena for academic discussion and exchange of ideas). Hence, most elements in the artworld will be reluctant to call these exercises art activities.

One possible objection is to say that I am simply employing one form of essentialist notion of art to deny these activities the status of art. In order to explain this objection we must first restate the four conditions above in a positive manner, i.e., (1) the artist must intend to present his activity as art; (2) organisers of, and participants in, the activity should consider their performance as art; (3) the activity must have an aesthetic function; and (4) the spectators must consider the activity as art. The objection is that I have rejected the Umsonst activities and soma exercises as art simply because they failed to fulfil conditions (1) to (4). It can then be argued that my position is weak because (1) to (4) cannot be considered as the necessary and sufficient conditions of art; one can easily think of examples which do not satisfy one or some of these conditions (e.g., Ming porcelain bowls that have been elevated to the status of art and are now kept in art museums may not satisfy the first two conditions). Firstly, I want to stress that the characteristics listed in (1) to (4) above are not meant to be necessary and sufficient conditions, but rather as what Wittgenstein $(1958,32)$ calls "family resemblances" in his Philosophical Investigations. None of these is necessary to art, but if a work lacks too many of these family resemblances, we can legitimately doubt its status as art. However, I have yet to discuss the strongest reason for doubting these political protest activities as art (which I shall do in the conclusion).

\section{Eliminating the Distinction between Art and Its Surrounding Environment}

I have so far taken an anti-essentialist line, labelling characteristics (1) to (4) above as "family resemblances" rather than necessary and sufficient conditions of art. There is however one condition which (at least at the present moment) is still necessary if not sufficient-i.e., we still make a distinction between art and nonart; or there is at least some way we demarcating art and non-art. This demarcation may not always be clear (some have argued that new movements and creations constantly blur the distinction), but this does not imply we no longer expect the demarcation to exist, or we do not make the distinction (between art and its environment) when we deal with new art forms. If this demarcation is ever obliterated, one wonders if art need continue to exist at all. 
I will now proceed by arguing that: (a) radical politics could have obliterated the physical separation (or line of demarcation) between art and its environment, but this does not by itself destroy the distinction between art and non-art (for we can still mentally maintain the distinction between the two categories); however (b) radical politics also obliterates our mental separation between art and non-art (which happens when the criteria of evaluation for the two activities completely overlap), and this will make the existence of art completely redundant.

Now, art traditionally employs devices or means to separate itself from its surrounding environment so that it is not viewed as an extension of daily life. The framing of pictures, the use of pedestals in sculptures, the employment of melody and elevated diction in drama, the utilisation of stage and props in opera, etc., are meant to delineate the artwork from the surrounding environment so that it is not seen as an extension of normal activities in daily life. This enables the artwork to be seen as an intelligible and coherent whole, without in any way connected to events in its surroundings.

But this separation has been challenged early in the 20th century when playwrights or actors invited members of the audience to perform in their drama (improvisation was needed as these invited spectators added their performances to the drama). Although this may erode the separation between actors and spectators (for spectators are taking over the role of the actors), it does not really affect the traditional separation between art and daily life. The spectator was simply acting when he took the stage to perform his piece (i.e., he temporarily entered the realm of art), but re-entered the realm of daily life once he steps from the stage after his "acting." So technically there still is a separation between art and its surrounding environment.

Radical artists (radical politics) are working to eliminate this distinction by making art activity an extension of daily life. Let us consider the Berlin and Hamburg Umsonst protest activities as examples. Anja Kanngeiser (2008, 5) describes the Umsonst activities as "collective playful interventions and appropriations which focus on everyday realm as their contextual frame." I will later discuss the employment of "collective interventions and appropriations" and focus first on (what is meant by) the "everyday realm." Kanngeiser $(2008,5)$ refers to Alistair Bonnet's description of everyday life as what was left in a day's activities after discounting all "specialised activities." She (Kanngeiser 2008, 5) then explains "specialised activities" with Bonnet's claim that it refers to "those activities commonly held to be responsible for the innovative, imaginative qualities attributed to literature, buildings, paintings, films and so on." In Bonnet's view, "everyday space... is that space in which creativity is conventionally absent" (see Kanngeiser 2008, 5). So everyday space includes 
whatever activities one is engaged in, as long as it is not in production of the arts. It is not unreasonable to consider this "space" as the routines of daily life. How, then, does radical art break into this routine of daily life, hence destroying the traditional distinction between art (or art activity) and daily life? The Umsonst activists engaged in what they call "play" (or what Kanngeiser calls "collective playful interventions and appropriations") - and it is this which allows us to see their activities as an extension of daily life. In other words the activists try to engage the spectators in fun, laughter and jokes, and also encourage them to participate in their activity. When invading Kreuzberg Badeschiff swimming pool in Berlin, the activists came in inflated boats. Kanngeiser $(2008,12)$ says that "the laughter provoked by the Bedeschiff action, the revelry inspired by the laughter of the activists and the reciprocity of laughter from the spectators, acts as a contagion for generating relationships. Laughter may act to prompt a feeling of reciprocity, of something shared. This spontaneous shared-ness can in turn invoke a certain sense of participation from within." Activists sometimes ran rings around the police who came to restore order, provoking laughter and participation from the spectators (see Kanngeiser 2008, 10-11). The important thing here is there is no longer the need for suspension of disbelief. Now, we need to suspend disbelief while watching a drama, reading a novel, contemplating the action in the painting, etc. Suspension of disbelief is needed because these traditional art forms create their own space and time-we can only enter this created space and time zone if we suspend disbelief and follow the action (in a drama or novel or movie) as if it were real. Furthermore, it is our willingness to follow the events (or the action) as if it were real, that allows the relevant emotions to be aroused in us (the spectators). It is our suspension of disbelief that allows a tragic drama, such as Sophocles' Oedipus Rex, to evoke pity and fear in us. If a spectator completely disbelieves the action in the drama, movie, or novel, the emotions which are expressed in the artwork will not be aroused at all. On the other hand, spectators in the Umsonst protests need not suspend disbelief largely because they did not create another space and time zone - the spectators and protestors interact in real time and space. The spectator need not suspend disbelief in order to be provoked to laughter, or feel togetherness and affinity with the protestors. It is in this way that radical art intrudes into daily life - as a spectator interacts with the protestors, this interaction becomes a part of his daily life (he is not acting, as in the case of the spectator who was called to stage to act his part). And this obliterates the traditional physical separation between art and its surrounding environmentwith radical art we can no longer determine the boundary between art and nonart; we no longer know where it begins and where it ends.

But this obliteration of the physical boundary between art and its environment does not necessarily mean we can no longer distinguish between art and non-art. We can still mentally make the distinction between the two categories; even with 
the Umsonst activities (e.g., I can say that anyone who was in the crowd but does not believe in the motto "the luxuries of cultural and aesthetic life should be made available to the masses" is not part of the art; or anyone in the crowd who does not actively participate in the protest action is not part of the artwork, etc. Radical politics may have made it difficult to physically demarcate the "art activity" from its surroundings, but this does not stop us from constructing a mental distinction between the two. What can really obliterate our mental distinction is the overlapping of the criteria for assessing the activity as "art" and as political protest (i.e., "non-art").

\section{How Do We Evaluate Radical Politics from the Viewpoint of Aesthetics?}

How do we judge the success or failure of radical politics as art (or as art activity)? In other words, what kind of value-conferring features do we look for when we wish to analyse it aesthetically? We certainly cannot employ criteria for assessing the more traditional art forms, like the presence of unity, harmony, balance, expression of certain emotional or mental states, representation of certain objects, etc. Neither can we employ criteria traditionally used for drama or the literary works, such as the presence of plot, revelation of character, employment of elevated diction including the use of metaphors, appropriateness of the chorus or background music, etc. These features are either absent or completely inappropriate when viewing a radical protest (one may say we could analyse the beauty of poems that were read to the protestors, or the expressiveness of songs sung in the protest. But these are only incidental parts of the entire protest, which could have proceeded without poems or songs. Besides, there are many purely political protests that contain poems and songs, but having these features does not make them works of art-for example the Thai redshirt protests of 2010. What we want are aesthetic features that are peculiar to radical politics). One may argue that we should look for entirely new criteria when evaluating radical protests (or radical politics) as art; after all it is supposedly a new art form. But what "new" criteria may emerge from this search? Ultimately we may be forced to conclude that the "new" criteria do not exist, or return to the objectives of the protest and view its success or failure in achieving them. We may then employ criteria which can be phrased in questions like: "how effective was this protest in gaining support from the general population?"; "how effective was this action in changing people's views on inequality in society?"; "how successful was the Hamburg Umsonst protests in raising awareness that the working class is equally entitled to the luxuries of life?"; etc. In other words, the criteria employed for assessing a radical protest activity from the (so-called) aesthetic perspective will be completely similar to those we employ for viewing it from the angle of politics. In terms of criteria for evaluation, radical art is exactly the same as political activism (viewing it as art activity is no different from seeing it as political protest). From the angle of evaluation then, 
there is no reason to call these activities "art" (or even "aesthetic activities"), they might as well retain their status (or continue to be known) as political protests. Once art loses its distinctiveness in this way, it could become pretty redundant.

There is therefore a good possibility that the artworld may reject radical politics as art. Now I am not saying that the artworld will certainly reject radical politics, for there is no way to accurately predict what changes or transformation the artworld may undergo in the future. But given that we presently still make a distinction between criteria for aesthetic analysis and those which are not for aesthetic judgment (to talk about whether Michelangelo's David can be effectively used as an infantry weapon in medieval warfare is not to judge it from the aesthetic perspective), there is a likelihood that radical politics may not enter the realm of the art despite attempts by certain quarters to confer upon them the status of "arthood." And as long as that possibility exists, I can assert that Dickie's definition may not have laid out the sufficient conditions of art-for something that is an artefact and which has had conferred upon it the status of candidate for artistic appreciation by someone acting on behalf of the artworld (e.g., a book like Aesthetics and Radical Politics) may still not qualify as art in the long run. The best examples are activities in the realm of radical politics (which have been discussed in this paper).

The major problem with the institutional theory of art (especially the one proposed by Dickie) is its inability to explain failures that have satisfied all the conditions described in its definition. Radical politics as art satisfies Dickie's two conditions of artifactuality (they are certainly products of human conception or agency) and the presence of attempts to confer the status of art-hood on thembut they would probably end up being overlooked or ignored by the artworld for reasons that I have stated above. The institutional theory has failed as an essentialist definition because it has either not supplied the complete list of sufficient conditions of art, or has not identified the true essentialist features of art. Or perhaps the anti-essentialists are right, i.e., there are no necessary and sufficient conditions of art.

\section{Conclusion and Solidarity}

Perhaps the greatest difficulty is to fit this paper with the theme of solidarity. The question is with whom do I express solidarity? My paper expresses solidarity with Morris Weitz and his supporters, even though I pointed out earlier that Weitz has left himself open to criticism for not taking hidden or relational properties into account (and that continuous innovation that emphasises new features does not imply the absence of essential properties). But my criticism of the institutional theory has reinforced my earlier claim that essentialist definitions 
are either too narrow, too broad, or both. Theories that describe second-order physical features, such as Clive Bell's Significant Form, tend to mention something that is neither the necessary nor the sufficient property of art (they tend to be both too narrow and too broad - too narrow because not all artworks have Significant Form, and too broad because certain things such as a beautiful landscape can also be viewed as having Significant Form). Theories that describe relational properties, such as the institutional theory, may not be so weak; but they still fail to identify the sufficient condition of art-this is because the definition gets too broad and includes attempts to confer the status of art which ended up as failures (the modern world may be filled with thousands of such cases). Based on such experience (essentialist definitions of art have been created for centuries beginning with Aristotle's definition of tragedy), it is very likely that another attempt to define art by its essence will probably end with similar weaknesses. Like Weitz, I believe it is more fruitful for aestheticians to strike in a new direction rather than carry on a practice that would probably not attain its ultimate objective. After all, knowledge of the so-called essential properties of art (if they really existed) is neither necessary for distinguishing art from non-art; nor evaluating and judging artworks. Both practices are carried out successfully even though we do not have a universally agreeable set of necessary and sufficient properties of art. As long as we have an expanding set of important features (none of which are necessary or sufficient for something to be seen as art), we will have enough indicators for determining whether something is a work of art, and (for) evaluating its effectiveness and quality as a work of art. Many items in this list have already been supplied by the essentialist aestheticians (even though they are not really the necessary or sufficient properties of art); such as the expression of peculiar emotions or mental states (Collingwood), the evoking of emotions in the spectators (Leo Tolstoy's notion of art as communication of emotion, and Aristotle's concept of katharsis), unification of parts or features into a coherent whole (which can be gleaned from Aristotle's definition of tragedy, and even Clive Bell's Significant Form), iconography and the expression of certain art-ideas (Panofsky, and supporters of conceptualist art), etc. It would be more fruitful for aesthetics to focus on further examining and perhaps even expanding on this list of important features, rather than continue searching in vain for the "real" essential properties of art. It is true that unlike Weitz I never argued that continuous innovation must necessarily imply the absence of essential properties, but I stand in agreement (and solidarity) with him in believing that given the failures of all previous essentialist theories, one must say it is most likely quite fruitless to continue the search for the essence of art.

I also stand in solidarity with those who feel a moral responsibility or even duty to expose poor theorising-which is obviously the goal of criticisms in philosophy (and aesthetics in particular). I want to see this as related to Wittgenstein's "therapeutic" conception of philosophy-i.e., eliminating 
"sickness" in philosophical misconceptions, which includes the belief that all concepts derive meaning from essential (or necessary and sufficient) properties. While most scientific terms like hydrogen, helium or sub-atomic particles derive their meanings from necessary and sufficient properties, many ordinary-language concepts do not function in the same manner - to think that all concepts including "art" must function in the same way (like most scientific concepts) is indeed a misconception. Eliminating such misconceptions would ensure that effort, time, and resources would be channelled towards "healthier" and more fruitful practices in the future.

\section{Bibliography}

Bell, C. 1958. Art. New York: Capricorn Books

Casey, J. 1973. The autonomy of art. In Philosophy and the arts: Royal Institute of Philosophy lectures, vol. 6, ed. Vesey, G. London and Basingstoke: The Macmillan Press Ltd.

Collingwood, R. G. 1958. The principles of art. New York: Oxford University Press.

Danto, A. 2007. Art as theory. In The nature of art: An anthology, ed. Wartenberg, T. E., 204-216. Belmont: Thomson Wadsworth.

Dickie, G. 2007. Art as institution. In The nature of art: An anthology, ed. Wartenberg, T. E., 217-225. Belmont: Thomson Wadsworth.

Ekstrand, L. and Wallmon, M. 2008. Basic income beyond wage slavery: In search of transcending political aesthetics. In Aesthetics and radical politics, ed. Grindon, G, 42-55. Newcastle: Cambridge Scholars Publishing.

Erler, A. 2006. Dickie's institutional theory and the "openness" of the concept of art. Postgraduate Journal of Aesthetics 3(3), 110-117.

Gardiner, M. 2008. Alexander Trocchi and situationism. In Aesthetics and radical politics, ed. Grindon, G., 63-82. Newcastle: Cambridge Scholars Publishing.

Goia, J. 2008. Soma: An anarchist experiment. In Aesthetics and radical politics, ed. Grindon, G., 56-62. Newcastle: Cambridge Scholars Publishing.

Gordon, G. 2008. Abolishing Bakunin: Towards and anarchist politics of text. In Aesthetics and radical politics, ed. Grindon, G., 104-127. Newcastle: Cambridge Scholars Publishing.

Grindon, G., ed. 2008. Aesthetics and radical politics. Newcastle: Cambridge Scholars Publishing.

Hagberg, G. L. 2002. The institutional theory of art: Theory and antitheory. In A companion to art theory, ed. Smith, P. and Wilde, C., 487-504. Oxford: Blackwell.

Hopkins, D. 2002. Marcel Duchamp's readymades and anti-aesthetic reflex. In A companion to art theory, ed. Smith, P. and Wilde, C., 253-264. Oxford: Blackwell.

Kanngeiser, A. 2008. The production of disruption: The subversive potential of play and desire in the actions of Berlin and Hamburg Umsonst. In Aesthetics and radical politics, ed. Grindon, G., 1-25. Newcastle: Cambridge Scholars Publishing.

Langer, S. 1957. Philosophy in a new key: A study in the symbolism of reason, rite, and art. Cambridge: Harvard University Press. 
Lok, C. H. 2007. Plato and Aristotle: Their views on mimesis and its relevance to the arts. Philosophia: International Journal of Philosophy 36(2): 119-140.

. 2010. Does Aristotle have a theory of art? Philosophia: International Journal of Philosophy 39(2): 124-145.

Mandelbaum, M. 1965. Family resemblances and generalization concerning the arts. American Philosophical Quarterly 2 (3): 219-228.

Plato. 1961. Republic, trans. Shorey, P. In The collected dialogues of Plato, eds. Hamilton, E. and Cairns, H. New York: Bollingen Foundation.

Schaper, E. 1968. Prelude to aesthetics. London: George Allen and Unwin Ltd.

Scruton, R. 1974. Art and imagination: A study in the philosophy of mind. London: Metheun \& Co. Ltd.

Trocchi, A. 1991. Invisible insurrection of a million minds: A Trocchi reader, ed. Scott, A. M. Edinburgh: Polygon.

Wartenberg, T. E., ed. 2007. The nature of art: An anthology. Belmont: Thomson Wadsworth.

Wittgenstein, L. 1958. Philosophical investigations, 3rd ed. New Jersey: Prentice Hall.

Weitz, M. 1956. The role of theory in aesthetics. Journal of Aesthetics and Art Criticism 15(1): 27-35. 